Jean-Pierre Tournadre MD, Murray Barclay MD, Paul Boulétreau MD, Dominique Chassard MD PhD

\section{Lower oesophageal sphincter tone increases after induction of anaesthesia in pigs with full stomach}

Purpose: The lower oesophageal sphincter (LOS) is the main mechanism that prevents gastro-oesophageal regurgitation during anaesthesia. The aim of this study was to assess the effect on lower oesophageal sphincter pressure (LOSP) of rapid sequence induction in pigs with full stomachs.

Methods: Lower oesophageal sphincter pressure and oesophageal barrier pressure $(\mathrm{BrP}=$ LOSP minus gastric pressure) were measured using a water-perfused manometric catheter method in 12 pigs after gastric filling with $500 \mathrm{ml}$ of liquid nutrient mixture. Six pigs were randomly allocated to receive $5 \mathrm{mg} \cdot \mathrm{kg}^{-1}$ propofol and $3 \mathrm{mg} \cdot \mathrm{kg}^{-1}$ succinylcholine iv, and six pigs received $8 \mathrm{mg} \cdot \mathrm{kg}^{-1}$ thiopentone and $3 \mathrm{mg} \cdot \mathrm{kg}^{-1}$ succinylcholine $\mathrm{iv}$.

Results: After induction, mean LOSP increased during the period with fasciculations from $19 \pm 4 \mathrm{mmHg}$ to $28 \pm 5 \mathrm{mmHg}$ in the propofol-succinylcholine group and from $23 \pm 6 \mathrm{mmHg}$ to $36 \pm 7 \mathrm{mmHg}$ in the thiopentone-succinylcholine group. The LOSP remained elevated after the fasciculations. LOSP and BrP were not different between the groups.

Conclusions: Induction of anaesthesia with propofol-succinylcholine or thiopentone-succinylcholine increases LOSP and, consequently, BrP in pigs with a full stomach. This increase begins before fasciculations and remains elevated for the period when intubation would occur.

Objectif : Le sphincter oesophagien inférieur (SOl) représente le mécanisme principal responsable de la prévention de la régurgitation gastrooesophagienne durant l'anesthésie. Le but de cette étude était d'évaluer l'effet sur la pression du sphincter oesophagien inférieur (PSOl) d'une induction en séquence rapide chez des porcs avec estomac plein.

Méthodes : La pression du sphincter oesophagien inférieur et la pression de barrière oesophagienne $(\mathrm{PBr}=$ PSOI moins pression intragastrique) ont été mesurées au moyen de la méthode du cathéter manométrique perfusé avec de l'eau chez 12 porcs chez lesquels l'estomac avait été rempli avec $500 \mathrm{ml}$ de mélange nutritif liquide. De façon aléatoire, six porcs ont reçu par voie iv $5 \mathrm{mg} \cdot \mathrm{kg}^{-1}$ de propofol et $3 \mathrm{mg} \cdot \mathrm{kg}^{-1}$ de succinylcholine et six porcs ont reçu par voie iv $8 \mathrm{mg} \cdot \mathrm{kg}^{-1}$ de thiopental et $3 \mathrm{mg} \cdot \mathrm{kg}^{-1}$ de succinylcholine.

Résultats : Après l'induction, la PSOI moyenne a augmenté durant les fasciculations de $19 \pm 4$ à $28 \pm 5 \mathrm{mmHg}$ dans le groupe propofol-succinylcholine et de $23 \pm 6$ à $36 \pm 7 \mathrm{mmHg}$ dans le groupe thiopental-succinylcholine. La PSOI est demeurée élevée après la fin des fasciculations. La PSOl et la $\mathrm{PBr}$ n'étaient pas différentes entre les deux groupes.

Conclusions : Linduction de l'anesthésie avec propofol-succinylcholine ou thiopental-succinylcholine augmente la PSOl et, par voie de conséquence la PBr chez des porcs avec estomac plein. Cette augmentation débute avant les fasciculations et demeure élevée durant la période où aurait lieu l'intubation.

From the Service d'Anesthésie-Réanimation Hôpital de l'Hótel-Dieu, 69002 Lyon, France.

Presented in part at the OESO World Congress, Paris, France, September 3-7, 1996 and at the 38th Congrès National d'Anesthésie et de Réanimation, Paris, France, September 26-29, 1996.

Supported by research grant n 0859 FC 9001 "Projet de recherche en Anesthesie et Reanimation 1995" Zencca Pharma France. Address correspondence to: Dr. J.P. Tournadre; Phone: 33-4-72-41-31-00; Fax: 33-4-72-41-31-35; E-mail: jptourna@ univ-lyonl.fr Accepted for publication February 11, 1998. 
$\mathrm{T}$ HE lower oesophageal sphincter (LOS) is the main mechanism to prevent regurgitation of gastric contents during anaesthesia. ${ }^{1}$ In full stomach situations, the risk of regurgitation is very high. Furthermore anaesthetic agents may alter LOS function decreasing the barrier against reflux of gastric content in the oesophagus. ${ }^{1}$ This alteration of LOS efficacy is particularly dangerous after induction of anaesthesia and before tracheal intubation, a period when upper oesophageal sphincter does not act efficiently. ${ }^{2}$ Thus, during this time, the LOS is the only mechanism to protect trachea against aspiration.

Rapid-sequence induction of anaesthesia or crashinduction with the combination of an anaesthetic agent followed immediately by succinylcholine has been recommended to avoid pulmonary aspiration in full stomach situations. ${ }^{3}$ There are very few manometric studies evaluating the effects of anaesthetic drugs on LOS function despite the now well recognised usefulness of oesophageal manometry for assessing the effects anaesthetic agents. ${ }^{4}$ Thiopentone decreases LOSP in humans ${ }^{5}$ but the effect of propofol on LOSP is unknown. Succinylcholine increases LOSP but this effect was studied during fasciculations or in animals in which the LOS is different from humans. ${ }^{4,6-9}$ There are no data about the action of this drug after the fasciculation period. Moreover lower oesophageal sphincter pressure (LOSP) has not been measured when these anaesthetic drugs are associated.

We, therefore, tested in pigs the hypothesis that anaesthetic induction could alter LOSP in full stomach situations and compared the effect of propofolsuccinylcholine and thiopentone-succinylcholine on oesophageal barrier pressure $(\mathrm{BrP})$.

\section{Methods}

Study design

After Institutional Animal Care committee approval, we studied 12 pigs (weight $22-25 \mathrm{~kg}$ ).

The day before each study, a laparotomy was performed under general anaesthesia. Anaesthesia was induced with $5 \mathrm{mg} \cdot \mathrm{kg}^{-1}$ propofol, $3 \mu \mathrm{g} \cdot \mathrm{kg}^{-1}$ sufentanil and $1 \mathrm{mg} \cdot \mathrm{kg}^{-1}$ atracurium, before tracheal intubation, and was maintained with a continuous infusion of 10 $\mathrm{mg} \cdot \mathrm{kg}^{-1} \cdot \mathrm{hr}^{-1}$ propofol. A lasso was inserted around the duodenum to achieve duodenal occlusion at the appointed time. The end of the lasso was fixed at the skin and the abdominal wall was closed in layers.

On the following day, $8 \mathrm{mg} \cdot \mathrm{kg}^{-1}$ ketamine im was administered as premedication. Then, LOSP, oesophageal and gastric pressure (GP) were recorded using seven water perfused polyethylene catheters (Multi-lumen probe, C71 A, Marquat, Boissy, France) which were introduced orally. The polyethylene catheters were connected to transducers (Bentley Trantec, Irvine, CA, USA) and were constantly perfused with $\mathrm{l} \mathrm{ml} \cdot \mathrm{min}^{-1}$ water using a low compliance infusion pump (200 $\mathrm{mmHg} \cdot \mathrm{sec}^{-1}$ ) (Type 871012 pump, Braun, Melsungen, Germany). ${ }^{10,11}$ The high pressure zone, which defined the LOS, was detected with a station pull-through technique ${ }^{10}$ and measurements were performed after a $25 \mathrm{~min}$ rest. Transducers were zeroed to the midchest position and calibrated using a water column before each recording. Pressure tracings were recorded using a multiple channel recording system (Kontron medical, Electronics, Watford, England).

After duodenal occlusion with the lasso, the stomach was filled with $500 \mathrm{ml}$ liquid nutrient mixture (Nutrison, Nutricia, Paris, France, $100 \mathrm{ml}=100 \mathrm{Kcal}$, osmolarity: $100 \mathrm{mOsm} \cdot \mathrm{L}^{-1}$ ).

Pigs were randomly allocated to receive one of two anaesthetic induction combinations. in the supine position. Six received $5 \mathrm{mg} \cdot \mathrm{kg}^{-1}$ propofol followed immediately by $3 \mathrm{mg} \cdot \mathrm{kg}^{-1}$ succinylcholine (PS group) and six received $8 \mathrm{mg} \cdot \mathrm{kg}^{-1}$ thiopentone followed immediately by $3 \mathrm{mg} \cdot \mathrm{kg}^{-1}$ succinylcholine (TS group).

Before complete respiratory paralysis (detected on LOSP recording), and during spontaneous ventilation, the LOSP was recorded at end expiration. Barrier Pressure was defined as $\mathrm{BrP}=\mathrm{LOSP}$ minus gastric pressure.

The LOSP and GP were continuously monitored. Data were collected before stomach filling, after stomach filling (baseline), during fasciculations and $40 \mathrm{sec}$ after fasciculations.

\section{Statistical analysis}

Values are expressed as mean $\pm \mathrm{SD}$. Data analysis was performed using commercially available software (Instat, GraphPad Software, San Diego, CA, USA). A Kruskal-Wallis nonparametric analysis of variance test was used to detect any changes in LOSP associated with induction of anaesthesia. A repeated measures two-way analysis of variance was used to determine any time and drug-dependent effects on LOSP, followed by a Bonferroni corrected multiple comparisons test. Statistically significant differences were confirmed with a nonparametric Wilcoxon paired test. Changes were considered statistically significant when the $P$ was $<0.05$.

\section{Results}

The LOSP, BrP and GP before stomach filling were in the normal range for pigs $(15 \pm 4 \mathrm{mmHg}, 11 \pm 4$ $\mathrm{mmHg}, 6 \pm 4 \mathrm{mmHg}$ repectively). ${ }^{11}$ After stomach filling LOSP, $\mathrm{BrP}$ and GP increased (Table). 
TABLE Effects of anaesthetic induction on lower oesophageal sphincter pressure (LOSP), gastric pressure (GP), and barrier pressure $(\mathrm{BrP}=\mathrm{LOSP}-\mathrm{GP})$ in pigs with a full stomach

\begin{tabular}{lllllllllll}
\hline & \multicolumn{3}{c}{ Baseline } & \multicolumn{3}{c}{ Fasciculation period } & \multicolumn{3}{c}{40 seconds after induction } \\
\hline & LOSP & GP & BrP & LOSP & GP & BrP & LOSP & GP & BrP \\
$\begin{array}{l}\text { Propofol-succinylcholine } \\
\text { group }\end{array}$ & $19 \pm 4$ & $12 \pm 3$ & $7 \pm 3$ & $28 \pm 5^{*}$ & $14 \pm 3$ & $17 \pm 6^{*}$ & $24 \pm 3^{*}$ & $13 \pm 3$ & $12 \pm 3^{*}$ \\
$\begin{array}{l}\text { Thiopentone-succinylcholine } \\
\text { group }\end{array}$ & $23 \pm 6$ & $11 \pm 3$ & $10 \pm 6$ & $36 \pm 7^{*}$ & $15 \pm 3$ & $21 \pm 6^{*}$ & $32 \pm 6^{*}$ & $13 \pm 3$ & $19 \pm 6^{*}$ \\
\hline
\end{tabular}

Data arc mean $\pm \mathrm{SD}(\mathrm{mmHg})$

${ }^{\star} P<0.001$, compared with baseline value

After induction of anaesthesia in the two groups, LOSP increased during the period of fasciculations from $19 \pm 4 \mathrm{mmHg}$ to $28 \pm 5 \mathrm{mmHg}$ in the propofolsuccinylcholine group and from $23 \pm 6 \mathrm{mmHg}$ to $36 \pm 7$ $\mathrm{mmHg}$ in the thiopentone-succinylcholine group $(P<$ 0.001 ). Lower oesophageal sphincter pressure remained high after fasciculations and during the $40 \mathrm{sec}$ after the fasciculations in the two groups: $24 \pm 3 \mathrm{mmHg}$ and $32 \pm$ $6 \mathrm{mmHg}$, respectively, at the end of $40 \mathrm{sec}(P<0.001)$. GP during fasciculations was not different from baseline. Lower oesophageal sphincter pressure and $\mathrm{BrP}$ were not different between the two groups throughout the study.

The absence of pharyngeal regurgitation was verified in each case with laryngoscopy.

\section{Discussion}

We have demonstrated that lower oesophageal sphincter pressure increases in response to anaesthetic induction using propofol-succinylcholine or thiopentone-succinylcholine. We showed that barrier pressure also increases. This constitutes an unexpected protection against regurgitation during induction of anaesthesia for the period when intubation would occur.

Hall et al. described a close relationship between the LOSP and reflux during anaesthesia such that reflux status depends on the numerical value of the LOSP. ${ }^{12}$ In their study reflux was uncommon if the LOSP value exceeded $7 \mathrm{mmHg}$ and was consistent if LOSP was $<5 \mathrm{mmHg}$. We did not evaluate reflux in our study but the LOSP values recorded after induction (> $28 \mathrm{mmHg}$ ) suggested that there was a strong protection against reflux when anaesthesia is performed using these drug combinations.

We used this animal model because the pig lower oesophageal sphincter is composed of smooth muscle fibres subjected to the same neuro-peptidie regulation as humans in a similar anatomical situation. ${ }^{13,14}$ Ketamine was administered as premedication as this drug has no effect on LOSP. ${ }^{15}$

Control of LOS tone is through a combination of myogenic properties and active tonic neural excita- tion. Most of the tone is due to the release of acetylcholine from excitatory neurones. It is generally accepted that parasympathetic nerves exert an excitatory effect on the LOS. This is supported by the observation that muscarinic agents cause contraction of the LOS in animals and humans. ${ }^{5}$ Beta adrenergic antagonists and alpha adrenergic agonists also increase LOS tone in humans. ${ }^{5}$

Fasciculations increase gastric and abdominal pressure. The increase in LOSP after succinylcholine has been attributed to an adaptive response to this increase in abdominal pressure. ${ }^{4}$ There are no previous studies assessing the effects of these drugs when combined in the setting of a rapid sequence induction.

Although the crural diaphragm is widely considered to be an integral part of the antireflux barrier, ${ }^{16}$ we showed that paralysis with succinylcholine did not decrease LOS tone. Our study, therefore, suggests that the diaphragm does not contribute to the basal tone of the LOS. To confirm this hypothesis one could record electromyographic diaphragmatic activity while neuromuscular blockade of the diaphragm was performed with different neuromuscular blocking agents. Such studies would allow better understanding of the role of the diaphragn in the "antireflux barrier," particularly during anaesthesia.

The explanation for the increase in LOS tone with succinylcholine, starting immediately after apnoea was induced and lasting for at least $40 \mathrm{sec}$, is probably multifactorial. There may be a direct effect of succinylcholine on the LOS via sympathetic pathways because succinylcholine stimulates presynaptic nicotinic receptors causing the release of norepinephrine. ${ }^{17}$ Also, succinylcholine is associated with a greater release of cathecolamines than are the non-depolarising neuromuscular blocking agents. ${ }^{18}$ This mechanism could explain the difference in LOS function in response to the induction of anaesthesia according to the neuromuscular blocking agent used. ${ }^{4}$

An alternative explanation for the changes in LOSP after succinylcholine injection may relate to abdominal muscles having active tone that acts to decrease abdomi- 
nal pressure ${ }^{19}$ mainly by holding back abdominal contents. Paralysis of these striated muscles increases abdominal pressure around the LOS, where the hydrostatic pressure is higher, particularly in the supine position and when the stomach is full. It is known that LOS tone increases in response to abdominal pressure increase. ${ }^{20}$

The increase in LOSP in our study began before induction of fasciculations and the pressure remained high during the period when intubation normally occurs. The LOSP recording was stopped before tracheal intubation even though this period is known to be associated with a high risk of regurgitation. The purpose of the study was to measure the effects of the anaesthetic agents for as long as possible after injection, before the onset of anoxia and hypercarbia which may themselves influence LOS function. Tracheal intubation takes longer to perform in pigs than in humans causing an increased risk of artefacts and a major stimulation of the sympathetic nervous system. ${ }^{18,21}$

If applicable to humans, the current study suggests that rapid sequence induction of anaesthesia increases LOS tone and $\mathrm{BrP}$ thus affording, during this period, protection against regurgitation.

\section{Acknowledgments}

The authors thank Professeur Peix, Director of Institut de Recherches Chirurgicales (Faculte Laennec 69008 Lyon France) where the major part of this study was performed, Mrs Finzi and Dupin for excellent technical assistance, and Mr Gardette, Ohmeda, France, for loan of a Modulus CD integrated anaesthesia machine.

\section{References}

1 Cotton $B R$, Smith $G$. The lower oesophageal sphincter and anaesthesia. Br J Anaesth 1984; 56: 37-46.

2 Vanner RG, Pryle BJ, O'Dwyer JP, Reynolds $F$. Upper oesophageal sphincter pressure and the intravenous induction of anaesthesia. Anaesthesia 1992; 47: 950-4.

3 Magorian T, Flannery KB, Miller RD. Comparison of rocuronium, succinylcholine, and vecuronium for rapidsequence induction of anesthesia in adult patients. Anesthesiology 1993; 79: 913-8.

4 Smith G, Dalling $R$, Williams TIR. Gastro-oesophageal pressure gradient changes produced by induction of anaesthesia and succinylcholine. $\mathrm{Br} \mathrm{J}$ Anaesth 1978; 50: $1137-42$.

5 Kublmann J, Konrad-Dalhoff I, Weibrauch TR. Which drugs should be studied by pharmacomanometry? Dig Dis Sci 1991; 36: 51S-61S.

6 Laitinen S, Mokka REM, Valanne JVI, Larmi TKI. Anaesthesia induction and lower oesophageal sphincter pressure. Acta Anaesthesiol Scand 1978; 22: 16-20.
7 Muravchick S, Burkette L, Gold MI. Succinylcholine induced fasciculations and intragastric pressure during induction of anesthesia. Anesthesiology 1981; 55: 180-3.

$8 R o e R B$. The effect of succinylcholine on intragastric pressure. Anaesthesia 1962; 17: 179-81.

9 Cook WP, Schultetus RR. Lower esophageal sphincter integrity is maintained during succinylcholine-induced fasciculations in dogs with "full" stomachs. Anesth Analg 1990; 70: 420-3.

10 Dodds $W$. Instrumentation and methods for intraluminal esophageal manometry. Arch Intern Med 1976; 136: 515-23.

11 Chassard D, Tournadre JP, Berrada KR, Boulétreau P. Cricoid pressure decreases lower oesophageal sphincter tone in anaesthetized pigs. Can J Anaesth 1996; 43: 414-7.

12 Hall $A W$, Moossa AR, Clark J, Cooley GR, Skinner DB. The effects of premedication drugs on the lower oesophageal high pressure zone and reflux status of Rhesus monkeys and man. Gut 1975; 16: 347-52.

13 Aggestrup $S$, Uddman $R$, Lindkaer Jensen $S$, et al. Regulatory peptides in lower esophageal sphincter of pig and man. Dig Dis Sci 1986; 31: 1370-5.

14 Landers $B R$, Jamieson GG. Response of porcine lower esophageal sphincter to increasing intraabdominal pressure. Dig Dis Sci 1987; 32: 272-9.

15 Chen K, Pan J, Ji X. The effects of three kinds of anaesthesia on lower oesophageal sphincter pressure. Can J Anaesth 1990; 37: S59.

16 Mittal RK, Rochester DF, McCallum RW. Effect of the diaphragm contraction on lower oesophageal sphincter pressure in man. Gut 1987; 28: 1564-8.

17 Nigrovic V. Succinylcholine, cholinoreceptors and catecholamines: proposed mechanisms of early adverse haemodynamic reactions. Can Anaesth Soc J 1984; 31: 382-94.

18 Derbyshire DR, Chmielewski A, Fell D, Vater M, Achola $K$, $S$ mith $G$. Plasma cathecolamine responses to tracheal intubation. Br J Anaesth 1983; 55: 855-60.

19 Froese $A B$, Bryan $A C$. Effects of anesthesia and paralysis on diaphragmatic mechanics in man. Anesthesiology 1974; $41:$ 243-55.

20 Tournadre JP, Chassard D, Berrada KR, Boulétreau $P$. Effect of pneumoperitoneum and Trendelenburg position on gastro-oesophageal reflux and lower oesophageal sphincter pressure. Br J Anaesth 1996; 76: 130-2.

21 Brossy MJ, James MFM, Janicki PK. Haemodynamic and cathecholamine changes after induction of anaesthesia with either thiopentone or propofol with succinylcholine. Br J Anaesth 1994; 72: 596-8. 